\title{
Economic Migration, the Last Frontier
}

\author{
Pedro Infante Mota \\ University of Lisbon
}

Moving goods and services is much easier than moving labor and obstacles to migration represent the biggest difference between the wave of globalization we are experiencing and that which occurred more than a hundred years ago. Universally, the General Agreement on Trade in Services (GATS) is the only multilateral treaty that specifically deals with the admission of migrants for labor purposes. Relevantly, according to some estimates, elimination of immigration controls would more than double the world's real income. Despite the prospect of such significant welfare gains, migration is the most sensitive of all aspects of globalization, one of the most virulent political issues in international law and the unexplored frontier of globalization. Political realities largely explain the resistance, especially in wealthy countries, to liberalizing the flow of workers.

Keywords: international movement of persons, mode 4 of the general agreement on trade in services, labor mobility agreements, brain drain

"A man is of all sorts of luggage the most difficult to be transported"1.

\section{HISTORICAL INTRODUCTION}

The right of free movement of persons, including the right to leave and return to their own country, "finds its origins in ancient philosophy and natural law". Articulating Socrates' vision, Plato wrote:

"After having brought you into the world, and nurtured and educated you, and given you and every other citizen a share in every good that we had to give, we further proclaim and give the right to every Athenian, that if he does not like us when he has come of age and has seen the ways of the city, and made our acquaintance, he may go where he pleases and take his goods with him; and none of us laws will forbid him or interfere with him. Any of you who does not like us and the city, and who wants to go to a colony or to any other city, may go where he likes, and take his goods with him" [Plato's Dialogues, Crito].

With rare exceptions (in China and Japan or in times of war and internal turbulence ${ }^{3}$ ), free movement across borders "was the rule (...) in the history of humanity"4. The immigration checks "only arose at the end of the 19th century and for specific categories of foreigners" 5. Until the first world conflict, international travel has rarely been subject to the use of passports, and borders can be crossed easily. Some countries were even eager to attract immigrants. The Government of Argentina, for example, offered in the 
mid-nineteenth century to European immigrants free transportation, automatic Argentine nationality and land because the country needed people to work in farms and factories and to make new investments ${ }^{6}$.

Nowadays, it is customary to read that migration is "the most sensitive of all aspects of globalization" "one of the most virulent political issues of international law", "the unexploited frontier of globalization" and that the obstacles to migration represent the greatest difference between the wave of globalization that we live and that which occurred more than a hundred years ago ${ }^{10}$. Indeed, the largest known migration flows occurred between the mid-19th century and the outbreak of the first world conflict ("the age of free mass migration") ${ }^{11}$, when approximately 55 million Europeans emigrated to the United States and 50 million Chinese and 30 million Indians emigrated (not always voluntarily) mainly to work in the British colonies in Africa and the Pacific ${ }^{12}$. The rule Laissez faire, laissez passer was encouraged primarily to attract a cheap and docile workforce or to populate new territories ${ }^{13}$, and it is maintained that $10 \%$ of the world workforce has been permanently relocated ${ }^{14}$.

Having increased the New World workforce by $1 / 3$ and decreased by $1 / 8$ that of European economies, massive transatlantic migration has reduced the wage gap between destination countries and some European countries $^{15}$. Emigration during the first wave of globalisation increased Irish wages by $32 \%$, Italians by $28 \%$ and Norwegians by $10 \%$; by contrast, immigration reduced Argentine wages by $22 \%$, Canadians by $16 \%$, Americans by $8 \%$ and Australians by $15 \%{ }^{16}$.

The new migration became politically controversial and, therefore, the United States introduced in 1917 a literacy test for new migrants ${ }^{17}$, a circumstance that, combined with the outbreak of the first world conflict and the restrictions on the movement of people resulting therefrom, put an end to the "Era of Mass Migration"18.

At present, the existing limitations on the international movement of workers are much more important when faced with those prevailing in the late 19th and early 20th centuries. The number of international migrants remained relatively stable between 1950 and 2017, fluctuating between 2.7 and 3.3\% of the world's population ${ }^{19}$, being today almost 272 million worldwide (almost two thirds are migrant workers), about $3.5 \%$ of the world's population ${ }^{20}$.

Despite its relevance, international migration suffers from an "institutional vacuum"21, a clear indication of the political sensitivity underlying it. On one hand, there is currently no international organisation regulating labour mobility in the same way, for example, that the World Trade Organisation (WTO) governs international trade in goods and services. Although not always consistently, several international bodies end up playing some role in international migration: the International Labour Organisation, the United Nations, the WTO, the United Nations High Commissioner for Refugees, the International Organization for Migration, etc. On the other hand, the cross-cutting nature of international migration entails its regulation by "an eclectic set of superimposed norms that are scattered throughout a wide array of overlapping fields (human rights law, trade law, humanitarian law, labor law, refugee law, maritime law, etc.)"22.

\section{THE “RIGHT" TO MIGRATE}

Since the specialised treaties on migrant workers have few ratifications (e.g. the International Convention on the Protection of the Rights of All Migrant Workers and Members of Their Families of $1990^{23}$, the most important UN treaty on the rights of migrants ${ }^{24}$ ), it turns out to be essentially the global human rights regulation to protect migration:

"Specialized treaties on migrant workers have been eclipsed by general human rights conventions that are widely ratified. (...) Besides the general principle of nondiscrimination and equality before the law, these instruments notably enshrine the right to leave any country and to return to one's own country, the right of children to acquire a nationality, due process guarantees governing expulsion, and protection against refoulement." ${ }^{25}$ 
Seen as "the par excellence founding act of the set of rules that make up international migration law"26, the right to emigrate is protected in numerous international treaties and declarations ${ }^{27}$, with few countries prohibiting the departure of their nationals (e.g. North Korea today, the restrictive policies of the Soviet Union that prevented the emigration of Jewish citizens in the first decades of the Cold $\mathrm{War}^{28}$ ). At the universal level, results from Article 12 of the International Covenant on Civil and Political Rights, ratified by a large number of countries from all regions of the world, that:

"1 - Everyone lawfully within the territory of a State shall, within that territory, have the right to liberty of movement and freedom to choose his residence.

2 - Everyone shall be free to leave any country, including his own.

3 - The above-mentioned rights shall not be subject to any restrictions except those which are provided by law, are necessary to protect national security, public order (ordre public), public health or morals or the rights and freedoms of others, and are consistent with the other rights recognized in the present Covenant" 29 .

Article 12, paragraph 2, applies to all persons (national and non-national) and the right to leave also covers "undocumented migrants in transit countries"

In contrast to the right to leave, the nature of which is customary ${ }^{31}$, countries continue to enjoy sovereign competence to allow or refuse entry of foreigners into their territory; where provided, the right to enter is the result of treaties. The International Convention on the Protection of the Rights of All Migrant Workers and Members of Their Families does not create any duty of admission for the benefit of migrant workers:

"Nothing in the present Convention shall affect the right of each State Party to establish the criteria governing admission of migrant workers and members of their families" (art. 79).

Consequently, the main limitation to the right to leave any country is "the lack of a correlative right to enter another country" 32 and hence there is, "under public international law, no 'right to migrate' as such" ${ }^{33}$.

Universally, the right to leave is accompanied by the right to enter only two very specific categories of migrants ${ }^{34}$. The first category concerns the right to enter your own country, as set out in international human rights law, and more specifically in paragraph 4 of Art. 12 of the International Covenant on Civil and Political Rights: "No one shall be arbitrarily deprived of the right to enter their own country". If interpreted in good faith and in accordance with its common meaning and being "the right to enter your own country" wider than that of nationality, the condition "in your own country" will naturally cover "residents who have acquired close and enduring connections with their state of residence" ${ }^{35}$. The right to entry is not, however, automatic or absolute, as it requires "a case-by-case assessment that depends on the individual ties of longterm residents with their country of establishment" 36 .

The second category concerns the entry of migrants into the provision of services, a situation regulated by the General Agreement on Trade in Services (GATS), "the only multilateral treaty specifically addressing admission for labour purposes" 37 , "the only universal instrument to explicitly govern the delicate issue of the admission of foreigners for economic purposes" 38 .

Leaving aside other examples of binding commitments limiting national sovereignty on migration ${ }^{39}$, some attention should be paid to so-called labour market integration agreements (Art. V-A of the GATS, also referred to as Art. V-bis), preferential trade agreements with provisions on labour mobility, bilateral temporary migration agreements and, most of all, GATS' mode $4^{40}$.

\section{LABOUR MARKET INTEGRATION AGREEMENTS}

With the epigraph "Labour Market Integration Agreements", Art. GATS V-A determines that: 
"This Agreement shall not prevent any of its Members from being a party to an agreement establishing full integration of the labour markets between or among the parties to such an agreement, provided that such an agreement:

(a) exempts citizens of parties to the agreement from requirements concerning residency and work permits;

(b) is notified to the Council for Trade in Services."

A footnote also goes ahead with some details about the term "full integration":

"Typically, such integration provides citizens of the parties concerned with a right of free entry to the employment markets of the parties and includes measures concerning conditions of pay, other conditions of employment and social benefits."

Since Article V-A of the GATS was adopted in particular to meet the needs of northern European countries that had fully integrated labour markets and did not want to risk the compatibility of their agreements with the GATS ${ }^{41}$, it is not surprising that the normally advanced example of a labour market integration agreement is the so-called Nordic Labour Market Agreement concluded between Denmark, Finland, Iceland, Norway and Sweden in March 1982 and entered into force on 1 August $1983^{42}$. According to their provisions, the labour market regulations of any contracting country may not place nationals of other contracting countries in a less favourable position compared to nationals of that country, i.e. nationals of a contracting country employed in another contracting country shall be treated in the same way as nationals of the country in relation to remuneration and other working conditions ${ }^{43}$.

\section{GATS MODE 4}

As most destination countries have no interest in eliminating all requirements on visas and work permits, the exception of GATS Art. V-A is rarely invoked ${ }^{44}$ and, above all, labour market integration agreements should not be confused with the services supplied under the much-referred GATS Mode 4 . The latter mean that an independent professional (or an employee of a foreign company operating abroad or established in the country of service supply ${ }^{45}$ ) travels to the territory of another country to supply a service (e.g. doctors, nurses, teachers or engineers) and leaves the country once the service has been supplied or elapsed the period of time previously specified. GATS Mode 4 does not therefore cover migration per $s e^{(46)}$ or permanent migration ${ }^{47}$.

By the definition of Mode 4 set out in Article $\mathrm{I}(2)(\mathrm{d})^{48}$, the nationality of the service supplier shall be different from that of the Member of the WTO in whose territory the service is supplied, i.e. the natural person shall be a national (or permanent resident) of a WTO Member other than the member in which he is present to supply the service ${ }^{49}$. Services supplied in the United Kingdom by an Indian citizen fall under Mode 4, unlike services supplied by a UK citizen or a Lebanese citizen (who is not a native of a WTO member country $)^{50}$. Otherwise, the suppliers of the country where the service is to be supplied would not be entitled, under the GATS, to appeal against their own government for measures affecting the access of foreign individuals who wished to employ. This right "would be vested only in foreign services companies or in foreign natural persons when they are themselves the service suppliers" 51 .

In addition, GATS Mode 4 may include independent suppliers paid directly by consumers or service suppliers under contract ${ }^{52}$ and covers the movement of persons only to the extent that such movement has to do with the supply of a service ${ }^{53}$, leaving outside its scope the work to be carried out in sectors, for example, mining, manufacturing or agriculture ${ }^{54}$.

Although the GATS is "colour/race/culture-blind" 55 , the obligations of market access (art. XVI) and national treatment (art. XVII) are also conditional in the case of the GATS, in the sense that it is each WTO Member who has the final say as to who enters its market, why, for how long and under what conditions ${ }^{56}$. Therefore, access to Mode 4 service suppliers is determined by the nature of the specific commitments of each WTO Member. This flexibility to condition, for example, national treatment offers WTO members 
who receive labour the possibility to protect their workforce from wage competition by foreign suppliers ${ }^{57}$. Although equal pay is a fundamental principle of Conventions No 97 (1949) and No 143 (1975) of the International Labour Organisation (ILO) on the protection of migrant workers ${ }^{58}$, the subjection of Mode 4 service suppliers generally to the minimum wage of the host country and other labour standards means that low-wage countries are deprived of their comparative advantage and hence the frequent attack on so-called wage-focused economic necessity tests by those who wish to increase the relevance of Mode 4, as "wage parity tends to erode the advantage of hiring foreign workers and actually functions as a quota"59.

It is also apparent from paragraph 1 of the Annex on the Movement of Natural Persons Supplying Services under the GATS that it:

"Applies to measures affecting natural persons who are service suppliers of a Member, and natural persons of a Member who are employed by a service supplier of a Member, in respect of the supply of a service" $" 60$.

And it is also clear from paragraph 2 of the Annex on the Movement of Natural Persons Supplying Services under Mode 4 the reason why this is often called the temporary presence of natural persons, given that it establishes the inapplicability of the GATS to:

"Measures affecting natural persons seeking access to the employment market of a Member, nor shall it apply to measures regarding citizenship, residence or employment on a permanent basis."

Given that the GATS and the 1993 Scheduling Guidelines do not specify what is meant as "permanent" or "non-permanent" in the host country, WTO members have interpreted this concept differently in their lists of specific commitments ${ }^{61}$, although only about a third of WTO members have specified maximum periods of residence for people covered by Mode 4 on your lists ${ }^{62}$. The expected periods tend to be longer for staff transferred within companies, with $88 \%$ of commitments allowing at least 36 months or not specifying a deadline; so-called business visitors can enter for considerably shorter periods, since $60 \%$ of commitments in this category restrict entry to less than three months ${ }^{63}$. A more recent study notes that, on average, between 3 and 5 years vary the scheduled lengths of stay for staff transferred within companies and between 3 months and 1 year, with very few lasting more than 2 years, for contracted service suppliers ${ }^{64}$. Where a WTO Member does not define the length of stay on his specific commitment lists, it is understood that no commitment has been made as to the duration of that period ${ }^{65}$.

The fact that Mode 4 is limited to temporary migration significantly reduces any concern about brain drain $^{66}$, i.e. the loss of skills and knowledge as a result of the migration of highly skilled workers abroad ${ }^{67}$, mainly from developing countries to developed countries ${ }^{68}$.

The brain drain not only limits the pool of talent available to employers in the country of origin, but also involves a transfer of public investment in education and training from the country of origin to the country of destination. Unsurprisingly, the Philippines has established a system that allows national nurses to work in the private sector or abroad if they pay their student loans ${ }^{69}$. Despite this, the Philippines is the world's largest exporter of nurses, but "because many qualified candidates choose not to emigrate or are unable to do so, the country has more nurses than Austria"70.

In general, an emigration tax (the so-called Bhagwati tax, a "surtax on the incomes of professionals from the least advanced countries in the countries of destination of immigration" ${ }^{71}$ ) could compensate developing countries for the brain drain, allowing countries to capture some of the benefits arising from the frequency of their public education systems. Some of the main criticisms of the Bhagwati tax relate to the uncertainty of the value of the tax losses in question ${ }^{72}$, the possible unconstitutionality of the destination country charging a tax on behalf and for the benefit of other governments ${ }^{73}$ and the inability of the country of origin to impose charges on migrants residing in the country of destination. Of course, the latter problem can be solved through international agreements or other cooperation agreements and any exit tax or 
Bhagwati tax would reduce migration incentives, except to the extent that the country of destination accepted it as the basis for a credit or deduction in its taxes ${ }^{74}$.

From the perspective of the migrant receiving country, temporary or permanent mobility can be used as a means of dealing with the scarcity of labour supply in sectors such as construction, hospitality and retail, increasing the flexibility of companies and helping to solve problems generated by low birth rates or by an aging population ${ }^{75}$. In the United Arab Emirates and Kuwait, for example, international migrants account for 88 and $76 \%$ of their national populations respectively. In 2018, the foreign-born population represented $13 \%$ of the population in all countries of the Organisation for Economic Co-operation and Development (OECD), compared to $9.5 \%$ in 2000, with the proportion of overseas births being higher in Luxembourg (48\% of the total population), Switzerland (29\%), Australia (28\%) and New Zealand (23\%) ${ }^{76}$. In the European Union, births (- deaths) contributed only 20\% to population growth between 2012 and 2016, while net migration added $80 \%$ to the total population increase ${ }^{77}$.

It is also very revealing that $53 \%$ of physicians in Australia and 29\% in the United States of America are immigrants ${ }^{78}$; that, between 1977 and 2015, academics associated with American institutions have won $65 \%$ of all Nobel prizes in scientific fields (Chemistry, Medicine, Physics and Economics), but that "only" $46 \%$ of these awards have awarded scientists born in the United States ${ }^{79}$; that, in $2013,56 \%$ of jobs with a high component of science, technology, engineering and mathematics were occupied by foreigners (70\% for software engineers in Silicon Valley) ${ }^{80}$; that many private start-ups that are now valued at more than $\$ 1$ billion have been created by immigrants (e.g., Google, Instagram, Uber and eBay) ${ }^{81}$; and that migrants are two to three times more likely to register patents than non-migrants ${ }^{82}$.

However, although the GATS-specific commitment lists establish links between the various modes of service provision, they mainly favour staff transferred within companies (intra-corporate transfers). In addition, more than half of all commitments made regarding GATS Mode 4 are conditional on the commercial presence of a GATS mode 3 foreign service supplier and, as such, the temporary labour movement is "complemented by the parallel flow of foreign capital inflow" to the highly skilled workforce and generally developing countries tend to be net importers of this type of labour, as their comparative advantage lies in relatively low-skilled and labour-intensive services ${ }^{84}$. Finally, certain developing countries have included a kind of local content requirement in their commitments to GATS Mode 3 in order to ensure that foreign companies establishing a commercial presence on their territory use local workforce ${ }^{85}$.

Although GATS Mode 4's contribution to temporary mobility is very small so far ${ }^{86}$, India has in recent decades become a relevant exporter of IT services and related activities, with the United States and Canada as the main importers ${ }^{87}$. In 2017, Indian exports in the information technology sector exceeded US $\$ 52$ billion, of which about $13 \%$ were exported through the use of professionals abroad (Mode 4) ${ }^{88}$. The GATS also owes the inclusion of Mode 4 to the Indian negotiators involved in the Uruguay Round (1986-94), who sought to balance the acceptance of GATS Mode 3 (advocated by developed countries) with the workforce movement in which developing countries tend to have comparative advantages ${ }^{89}$. The United States, on the other hand, proposed during the Uruguay Round that the mobility of the labor force be limited to the temporary entry of senior executives ${ }^{90}$.

While general exceptions relating to measures relating to public policy, health, the environment and security (Articles XIV and XIV-A of the GATS) restrict the right of a natural person to supply a service under Mode 4 and the right to reside temporarily in the territory of a host country for that purpose, some authors also consider that the extremely limited nature of the liberalisation commitments made so far on the movement of natural persons is partly due to the lack of safeguard instruments to compensate those affected by freer migration ${ }^{91}$. As we are looking at a mode of provision of great interest to developing countries and one in which almost all countries maintain severe restrictions, perhaps we can consider a safeguard instrument limited to Mode 4 liberalisation commitments ${ }^{92}$. But the use of safeguard measures would only be defensible when liberalisation commitments on the "presence of natural persons" have a detrimental and unpredictable impact on the societies of the destination countries ${ }^{93}$.

The very fact that the GATS is the only multilateral agreement incorporating binding provisions on the cross-border movement of persons (limited, however, to service suppliers) does not erase the rudimentary 
nature of the rules on (temporary) migration, mainly because agricultural workers (the main group of economic migrants) and visa policy are left out of their jurisdiction, which is the main barrier to the free movement of people. Visa fees are usually very onerous in relation to the average per capita income of countries of origin and there is often great uncertainty as to whether the time and money invested will result in obtaining a visa ${ }^{94}$. Hence India's proposal to include provisions on a fast-track visa procedure in the GATS for foreign service suppliers covered by the horizontal and sectoral commitments undertaken by a WTO Member, the so-called "Mode 4 visa" ". Significantly, the service industry associations of the United States and the European Union have come forward with similar proposals ${ }^{96}$.

\section{PREFERENTIAL TRADE AGREEMENTS}

The mobility of the labour input is often recognised as a central component of economic integration (mainly deep), together with the free movement of goods, services and capital. The geographical coverage of trade agreements is very broad, covering all regions of the world and more than 30 regional bodies have endorsed the free movement of persons as an objective, but the exact scope and content of the provisions governing the movement of people vary considerably ${ }^{97}$. While many preferential trade agreements comprise the movement, for example, of investors or dependents ${ }^{98}$, there are very few that cover migrant workers seeking employment or undocumented migrants. According to a recent study, 72 of the 100 preferential trade agreements covering visas and asylum explicitly exclude employment on a permanent basis, i.e. migration in preferential trade agreements is mainly limited to temporary movement ${ }^{99}$ and it is proven that moving goods and services is much easier than moving labour. The Comprehensive Economic and Trade Agreement (CETA) itself between the European Union and Canada, which has achieved one of the most advanced accesses to GATS Mode $4^{100}$ :

"Applies to measures adopted or maintained by a Party concerning the temporary entry and stay into its territory of key personnel, contractual services suppliers, independent professionals and short-term business visitors. This Chapter shall not apply to measures affecting natural persons seeking access to the employment market of a Party, nor shall it apply to measures regarding citizenship, residence, or employment on a permanent basis" (Art. 10.2(2).

The virtues of the free movement of people as a tool of economic development have been recognized mainly "among neighbouring states with similar levels of economic development" 101 . Moreover, a very "fresh" study concludes that:

"Other than in some regional economic communities, they do so in a "thin" way, focusing on procedural issues rather than genuinely opening migration flows. This is especially true in North-North Preferential Trade Agreements (only rarely in South-South Preferential Trade Agreements) and with a heavy focus on the temporary movement of high-skilled or specialized individuals, most often excluding the movement of people looking for work or permanent employment. In this sense, although cross-issue bargains could be struck within Preferential Trade Agreements so as to liberalize not only goods and services but also the movement of people, the contribution of Preferential Trade Agreements to the broader system of liberalizing or managing migration flows remains limited."102

Another study concludes, however, that the signing of a preferential trade agreement (regardless of its content) stimulates bilateral migration by $24 \%$, that preferential trade agreements including visa and asylum provisions stimulate bilateral migration flows by $35 \%$ and that preferential trade agreements that include clauses regulating labour markets between member countries stimulate bilateral migration flows by $39 \%{ }^{103}$. 


\section{BILATERAL TEMPORARY MIGRATION AGREEMENTS}

With regard to preferential trade agreements, bilateral temporary migration agreements enjoy the advantage of being able to be negotiated in response to economic cycles and to ensure access levels also for low-skilled workers ${ }^{104}$, whose movements governments are not prepared to liberalise in the context of preferential trade agreements or the GATS ${ }^{105}$. Occasionally, bilateral labour agreements make it possible for industrialised countries to welcome more skilled workers to the health or information technology sectors.

In 2017, more than 4.9 million migrant workers entered OECD countries through temporary labour migration programmes for the tourism, agriculture, forestry, construction and other sectors ${ }^{106}$ and some of the agreements concluded deal with issues that are outside the WTO's reach, such as repatriation of illegal migrants, training and general provisions on immigration ${ }^{107}$.

Today, bilateral temporary migration agreements are of particular relevance in the case of seasonal agricultural programmes in many OECD countries and, historically, the so-called bracero programme (which began in 1942) has covered more than 450000 Mexican workers per year ${ }^{108}$. The North-American program ended in 1964 with the aim of improving the wages and working conditions of U.S. rural workers ${ }^{109}$, but the abolition of the program did not achieve the expected results in the states most affected by the exclusion ofbraceros compared to other states:

"The reduction in labour supply brought about by the end of the programme leads some firms to switch to the advanced technology, but it does not change the land/labour ratio used by each technology and hence does not change the marginal product of labour." 110

\section{FINAL CONSIDERATIONS}

Given that in 2015 the ratio between the average income of high-income countries and that of lowincome countries was 70:1 ${ }^{111}$, migratory pressures are likely to continue in the near future. On the other hand, the fears of rich countries about the erosion of their cultural identity, the problems of assimilation of immigrants, the increase in public spending, etc., make unlikely that the barriers to labour mobility no longer represent the greatest distortion of the international economy ${ }^{112}$ and that there will be a mass migration of less skilled workers from poor countries to rich countries in the near future ${ }^{113}$.

Typically, local populations believe that immigrants steal the employment of workers in the destination country, contribute to the reduction of wages, burden public services (e.g. medical care and education), do not pay sufficient taxes, threaten national cohesion, etc. The United States immigration statutes, for example, state that "any foreigner which, within five years of the date of entry, became a public charge... is deportable"114. During the presidential campaign, Donald Trump even stated that Mexican immigrants were criminals ${ }^{115}$ and, when president, came to propose in May 2019 an additional customs duty of $5 \%$ on imports from Mexico, a value that would "gradually increase" until the flow of undocumented immigrants was stopped ${ }^{116}$, but ultimately did not take forward such an idea ${ }^{117}$.

In the European Union itself, often praised for its social model, Austria implemented in January 2019 a new law adapting benefits of the family to a value proportional to the purchasing power of the country of origin for the European Union citizens working in Austria; and was approved in November 2018 a new law to reform the minimum income regime, being the lowest value for candidates who have not completed compulsory education in Austria and do not have intermediate knowledge of German (B1) or advanced knowledge of English $(\mathrm{C} 1)^{118}$.

The wealthiest countries still spend huge sums on controlling the entry of migrants, with the United States, for example, disbursing \$18 billion in control of its borders in 2012 alone ${ }^{119}$ and it is estimated that the costs of the wall the Trump Administration began building along the border with Mexico amount to US $\$ 18$ billion, excluding maintenance costs ${ }^{120}$.

However, most existing studies (commonly focused on rich OECD countries) conclude that the economic effects of migration in the countries of destination are generally positive ${ }^{121}$. Specifically, a 2016 
study suggests that "a 1 percentage point increase in the participation of migrants in the adult population in advanced economies can increase GDP per capita by up to $2 \%$ in the long term" ${ }^{122}$. Not only is the overall impact of immigration on the wages of workers in the host country at most modest ${ }^{123}$, but migrants also increase labour productivity, often filling gaps in the labour market, especially in countries with an ageing population; work in sectors where low-skilled and highly skilled workers are scarce (farms, nursing, highly skilled manufacturing and technology); and contribute to the economies of host countries by paying taxes and spending about $85 \%$ of their salaries in them, with the remaining $15 \%$ sent as remittances to the country of origin ${ }^{124}$.

Even with regard to the so-called "brain drain", it must be held that labour mobility has always been a powerful tool to alleviate poverty ${ }^{125}$. The average foreign worker from a less developed country can expect to increase their salary five times if they emigrate to the United States ${ }^{126}$ and the migrants send a lot of money home ${ }^{127}$. Some countries, such as Indonesia, even encourage emigration because of the remittances that result from it ${ }^{128}$. An engineer who earns $\$ 6000$ a year in Indonesia can earn $\$ 60,000$ in the United States and send to his home country all the value he used to get at home.

It should also be noted that families receiving remittances tend to have children who remain in school for more years compared to families that do not receive them ${ }^{129}$. And unlike international donor funds, remittances tend to flow directly to intended recipients and not wasted or diverted by corrupt officials. Remittances are also more reliable than foreign investment, being counter-cyclical, i.e. foreign investors flee when a crisis begins, but migrants feel compelled to help even more their relatives at home ${ }^{130}$.

In addition, migration helps reduce transaction costs and other types of information by facilitating trade and flows of foreign direct investment, and is a channel for transferring technology and strengthening human capital in developing countries, enabling service suppliers to accumulate knowledge and experience during their stay abroad ${ }^{131}$, that is, "brain drain can be transformed into cerebral circulation" ${ }^{132}$. For example, experience in the information technology sector in India indicates that GATS Mode 4 is associated with more foreign investment, both internal and external, and many Indian professionals who have worked in the United States have had a significant influence on the decision of U.S. multinationals to establish activities in India. Subsequently, Indian Information Technology companies, such as Wipro and Infosys, established overseas subsidiaries or partnerships (GATS Mode 3) ${ }^{133}$.

Being still true that brain drain can lead to labour shortages in certain relevant activities (e.g. when the emigration of engineers or health professionals impairs the country of origin's ability to adopt new technologies or deal with health crises) ${ }^{134}$ and that global migration patterns are increasingly asymmetric ${ }^{135}$, it is also exact that the majority of qualified individuals from developing countries do not emigrate ${ }^{136}$ and that medical professionals constitute only $12-15 \%$ of educated immigrants ${ }^{137}$. Generally, the average developing country has $7.3 \%$ of its population with higher education in higher income countries ${ }^{138}$.

International migration can even influence the political (and economic) trajectory of nations, and may change the political beliefs and preferences of emigrants ${ }^{139}$. Migrants absorb new norms, practices and political information abroad, which they can then pass on to their communities of origin ${ }^{140}$.

Finally, some aspects that we deem relevant should be noted. First, the 2030 Agenda for Sustainable Development integrates migration into 10 of the 169 sustainable development goals ${ }^{141}$, and the following should be highlighted:

8.8 Protect labour rights and promote safe and secure working environments for all workers, including migrant workers, in particular women migrants and those in precarious employment;

10.7 Facilitate orderly, safe, regular and responsible migration, including through the implementation of planned and well-managed migration policies;

10.C By 2030, reduce to less than 3 per cent the transaction costs of migrant remittances and eliminate remittance corridors with costs higher than 5 per cent.

Second, companies have found in recent years that it can often be cheaper to move production abroad than to hire foreign workers, and, in this sense, the use of outsourcing and foreign direct investment can reduce incentives for migration. The very fact that the liberalisation of international trade generally implies more prosperity and wealth (even in the poorest regions), greater product diversity, lower prices, etc., may 
also have an impact on migration incentives. Conversely, protectionism, especially agricultural, displaces or destroys jobs in the poorest countries and can encourage migration ${ }^{142}$.

Third, digital technology is enabling the manpower to be separated from its physical location through remote work, facilitating the execution of tasks in "our" offices by foreign employees ("It is making it seem almost as if these foreigners are actually in the room and speaking the same language" ${ }^{143}$ ) and reducing (in terms of production) the impact of controls on migration. Relevantly, digital technologies enable companies to exploit wage differences between countries or regions and expand the range of jobs directly subject to international competition. As a general rule, "telemigrants" earn lower salaries, since they live in countries where the cost of living is lower, are not subject to the same labour laws, do not claim compensation, paid leave, social security contributions or maternity and paternity leave, etc. ${ }^{144}$ Although the increase in telemigration may lead to accusations of "social dumping" by workers in rich countries ${ }^{145}$, there is an increasing number of companies from rich countries using telemigrants. Companies from the United States, Australia and the United Kingdom are the ones that hire the most telemigrants and the Philippines, India and Bangladesh are the three largest sources of telemigrants ${ }^{146}$.

Finally, the most conservative estimates point to significant gains in terms of global well-being if the optimal allocation of the workforce between different countries became a reality, varying the gains between 5 and $12 \%$ of the world's real income, that is, between 2 and 4.3 trillion dollars per year ${ }^{147}$. Relevantly, migrants account for approximately $3 \%$ of the world's population, but produce more than $9 \%$ of global GDP, about $\$ 3$ trillion more than if they had stayed at home ${ }^{148}$.

\section{ACKNOWLEDGEMENT}

Translated \& edited by American Publishing Services (https://americanpublishingservices.com/).

\section{ENDNOTES}

1. ADAM SMITH, Inquérito sobre a Natureza e as Causas da Riqueza das Nações, Volume I, Translation and notes by Teodora Cardoso and Luís Cristóvão Aguiar, 4th ed., Calouste Gulbenkian Foundation, Lisbon, 1999, p. 190 [Book I, Chapter VIII].

2. JANE MCADAM, An Intellectual History of Freedom of Movement in International Law: The Right to Leave as a Personal Liberty, in Melbourne Journal of International Law, 2011, p. 32.

3. For example, the emigration of Portuguese merchants and missionaries to Japan since 1543 and the conversion of approximately half a million Japanese to Catholicism led the Shoguns to decide to expel foreigners (the "barbarians of the South") and to force the Japanese to renounce Christianity, under penalty of death. In 1635, the shogun forced the emperor to issue the so-called Closed Country Edict, ordering that:

"1. Japanese ships are strictly prohibited from leaving for foreign countries.

2. No Japanese is allowed to travel abroad. If there is anyone who tries to do it secretly, it should be executed. The ship involved must be seized and its owner arrested and the matter communicated to the higher authority.

3. If any Japanese return from abroad after residing there, he shall be sentenced to death." Forbidding their subjects' contacts with strangers, the shoguns wanted to keep the sacred land of Japan pure. MICHAEL H. FISHER, Migration: A World History, Oxford University Press, 2014, p. 72.

4. VINCENT CHETAIL, Sovereignty and Migration in the Doctrine of the Law of Nations: An Intellectual History of Hospitality from Vitoria to Vattel, in European Journal of International Law, Vol. 27, N. ${ }^{\circ} 4,2016$, p. 922.

5. VINCENT CHETAIL, The transnational movement of persons under general international law - Mapping the customary law foundations of international migration law, in Research Handbook on International Law and Migration, Vincent Chetail and Céline Bauloz ed., Edward Elgar, 2014, p. 30.

6. ANDRÉS SOLIMANO, International Migration in the Age of Crisis and Globalization: Historical and Recent Experiences, Cambridge University Press, 2010, p. 6.

7. ALAN WINTERS, The temporary movement of natural persons (Mode 4): The need for a long view, in Revitalising Multilateralism Pragmatic Ideas for the New WTO Director-General, Simon J. Evenett and Richard E. Baldwin ed., Centre for Economic Policy Research Press, London, 2020, p. 252. 
8. DIETER KUGELMANN, Migration, in Max Planck Encyclopedia of Public International Law, Oxford University Press, March 2009, paragraph 45.

9. DANI RODRIK, The Globalization Paradox: Why Global Markets, States, and Democracy Can't Coexist, Oxford University Press, 2011, p. 266.

10. MARTIN WOLF, Why Globalization Works, Yale University Press, New Haven and London, 2004 , p. 116.

11. VINCENT CHETAIL, International Migration Law, Oxford University Press, 2019, p. 39.

12. ANDREW BEATH, IAN GOLDIN and KENNETH REINERT, migration, international, in The Princeton Encyclopedia of the World Economy, Volume II, Kenneth Reinert and Ramkishen Rajan ed. Princeton University Press, 2009, pp. 764-765.

13. VINCENT CHETAIL, International Migration Law, Oxford University Press, 2019, p. 40.

14. JÜRGEN OSTERHAMMEL and NIELS PETERSSON, Globalization: a short history, Princeton University Press, 2003, p. 77.

15. ANDREW BEATH, IAN GOLDIN and KENNETH REINERT, migration, international, in The Princeton Encyclopedia of the World Economy, Volume II, Kenneth Reinert and Ramkishen Rajan ed., Princeton University Press, 2009, p. 765.

16. PETER LINDERT and JEFFREY WILLIAMSON, Does Globalization Make the World More Unequal?, in Globalization in Historical Perspective, Michael Bordo, Alan Taylor and Jeffrey Williamson ed., University of Chicago Press, 2005, p. 243.

17. Support for the restriction on immigration was based on concerns about competition in the labour market, as well as xenophobia and antipathy towards the arrival of new immigrants. RAN ABRAMITZKY and LEAH BOUSTAN, Immigration in American Economic History, in Journal of Economic Literature, 2017, p. 1319.

18. ANDREW BEATH, IAN GOLDIN and KENNETH REINERT, migration, international, in The Princeton Encyclopedia of the World Economy, Volume II, Kenneth Reinert and Ramkishen Rajan ed., Princeton University Press, 2009, p. 765. Immigration in the United States fell from 1.1 million people annually in 1913 and 1914 to 60,000 and 54,000 in 1918 and 1919 respectively. JEFFREY G. WILLIAMSON, The Political Economy of World Mass Migration: Comparing Two Global Centuries, The American Enterprise Institute Press, Washington, D.C., 2005, p. 26.

19. HEIN DE HAAS ET AL., International Migration: Trends, Determinants, and Policy Effects, in Population and Development Review, December 2019, p. 888.

20. INTERNATIONAL ORGANIZATION FOR MIGRATION, World Migration Report 2020, Geneva, 2019, p. 2.

21. ANDRÉS SOLIMANO, International Migration in the Age of Crisis and Globalization: Historical and Recent Experiences, Cambridge University Press, 2010, p. 18.

22. VINCENT CHETAIL, The Architecture of International Migration Law: A Deconstructivist Design of Complexity and Contradiction, in American Journal of International Law Unbound, Vol. 111, 2017, p. 18.

23. 56 ratifications on 18.6.2021 «OHCHR Dashboard" and none of the Member States of the European Union has ratified it yet. The states that have ratified them are mainly countries of emigrants and many receiving countries are reluctant to ratify the treaty because they believe that it will involve expanding state obligations and granting new rights to "illegal" immigrants. DAVID WEISSBRODT, Immigration, in Max Planck Encyclopedia of Public International Law, Oxford University Press, March 2014, paragraph 19.

24. Idem, paragraph 18.

25. VINCENT CHETAIL, International Migration Law, Oxford University Press, 2019, p. 71.

26. VINCENT CHETAIL, Droit international des migrations: fondements et limites du multilatéralisme, in $L a$ Société Internationale face aux Défix Migratoires, Habib Gherari and Rostane Mehdi ed., Pedone, Paris, 2012 , p. 35. The right to enter another country does not even "come into play if the antecedent right to leave one's country is not respected." JANE MCADAM, An Intellectual History of Freedom of Movement in International Law: The Right to Leave as a Personal Liberty, in Melbourne Journal of International Law, 2011, p. 28.

27. For example, the Declaration Human Rights of 10 December 1948 establishes in Article 13(2) that "Everyone has the right to leave any country, including his own, and to return to his country."

28. FIONA B. ADAMSON and GERASIMOS TSOUPARAS, Migration Diplomacy in World Politics, in International Studies Perspectives, 2019, p. 117. The Berlin Wall was erected in 1961 to prevent people from leaving East Berlin (dominated by the Soviet Union) to the West. Symptomatically, the end of the Cold War led to the emigration of more than 600,000 people from the former Soviet Union to Israel. WORLD BANK GROUP, Moving for Prosperity: Global Migration and Labor Markets, Policy Research Report, Washington, DC, 2018, p. 167. 
Currently, the Covenant is ratified by 173 states https://indicators.ohchr.org/.
VINCENT CHETAIL, International Migration Law, Oxford University Press, 2019, p. 81. We can distinguish between three types of migrants who are in a country without legally granted permission.

"1. An 'illegal' migrant may be somebody who crossed a national border without authorization and may be working in that country without the legal consent of the authorities of that country. Illegal immigrants are also sometimes referred to as 'undocumented' immigrants.

2. An 'irregular' migrant may be someone who entered a country legally - say, as a tourist - and then overstayed and took employment in breach of visa regulations or did not know where to extend a work visa. For years irregular immigrants pay taxes and are part of the community, even though their legal status as foreign residents is not fully regularized.

3. 'Criminal illegals' refer to immigrants who engage in criminal and unlawful activities in a foreign country, or foreigners engaged in narcotics trafficking or illegal arms dealing. In addition, migrant trafficking for exploitation belongs to a broader realm of criminal activity.

It is apparent that the breach of law is different in each case. In cases (1) and (2), the problem is the lack of compliance with immigration laws. In case (3) the offense goes beyond immigration laws, and it is certainly a more complicated case." ANDRÉS SOLIMANO, International Migration in the Age of Crisis and Globalization: Historical and Recent Experiences, Cambridge University Press, 2010, p. 43.

31. VINCENT CHETAIL, International Migration Law, Oxford University Press, 2019, p. 92.

32. VINCENT CHETAIL, International Migration Law: Foundations and bounds of the multilateralism, in The International Society in the face of Défix Migration, Habib Gherari and Rostane Mehdi ed., Pedone, Paris, 2012, p. 38.

33. MARION PANIZZON and HARJODH SINGH, Upping the Ante: The Movement of Natural Persons (Mode 4) and Non-Services Migration in EU and Asian PTAs, in Coherence and Divergence in Services Trade Law, R. T. Hoffmann and M. Krajewski ed., European Yearbook of International Economic Law, Springer, 2020, p. 145.

34. VINCENT CHETAIL, International Migration Law, Oxford University Press, 2019, p. 93.

35. Idem, pp. 93-94.

36. Idem, p. 95.

37. Ibidem.

38. VINCENT CHETAIL, International Migration Law: Foundations and bounds of the multilateralism, in The International Society in the face of Défix Migration, Habib Gherari and Rostane Mehdi ed., Pedone, Paris, 2012 , p. 62.

39. For example, although each country is allowed to establish its own procedures for deciding who should be recognised as a refugee (ALAN SYKES, International Cooperation on Migration: Theory and Practice, in University of Chicago Law Review, 2013, p. 339), paragraph 1 of the art. 33 of the Convention on the Status of Refugees 1951 (and amended in 1967 by the New York Protocol) enshrines the so-called non-refoulement (prohibition of expelling and repelling), the "cornerstone of international refugee protection" (United Nations High Commissioner for Refugees, Advisory Opinion on the Extraterritorial Application of Non-Refoulement Obligations under the 1951 Convention relating to the Status of Refugees and its 1967 Protocol, 26.1.2007, paragraph 5):

“No Contracting State shall expel or return ('refouler') a refugee in any manner whatsoever to the frontiers of territories where his life or freedom would be threatened on account of his race, religion, nationality, membership of a particular social group or political opinion.."

This principle of non-repulsion does not imply the right of an individual to receive asylum in a particular State. However, when states are not prepared to grant asylum to persons seeking international protection on their territory, they should not adopt behavior that results in the sending of such persons, directly or indirectly, to a place where their lives or freedom would be in danger because of their race, religion, nationality, membership of a specific social group or political opinions (United Nations High Commissioner for Refugees, Advisory Opinion on the Extraterritorial Application of Non-Refoulement Obligations under the 1951 Convention relating to the Status of Refugees and its 1967 Protocol, 26.1.2007, paragraph 8). The notion of social group has even allowed a certain expansion by including, for example, persecution on grounds of sexual orientation or forced marriages (OLIVIER DELAS, La création du principe de nonrefoulement en droit international des droits de la personne par la Cour européenne des droits de l'homme: 
un chef-d'œuvre à protéger, Revue québécoise de droit international Hors-série, 2020, pp. 401-402). Furthermore, the obligation not to return a refugee or asylum seeker to a country in which he is at risk of persecution or other serious harm (not necessarily the country of origin of the refugee or asylum seeker) is not subject to territorial restrictions and shall apply where a State has jurisdiction, including at the border, on the high seas or in the territory of another state (Advisory Opinion on the Extraterritorial Application of NonRefoulement Obligations under the 1951 Convention relating to the Status of Refugees and its 1967 Protocol, paragraph 24). Finally, the regularity or irregularity of an individual's entry into the territory of a State does not fall within the application of Article 33 of the 1951 Geneva Convention on the prohibition of expelling someone. This understanding is reinforced by Article 31 of the Same Convention itself (BENEDITA MENEZES QUEIROZ, A Proteção Internacional dos Refugiados: A Viagem até ao Refúgio, in Regimes Jurídicos Internacionais, Volume I, Universidade Católica Editora, Porto, 2020, p. 308).

However, the benefits arising from the principle of Non-Refoulement may not be invoked by a refugee if there are serious reasons to consider him a danger to the security of the country in which he is located, or that, having been object conviction for a particularly serious crime or offence, poses a threat to the community of that country (art. 33(2) of the Convention on the Status of Refugees). The reasons to consider the individual as a danger to the national security of the host country (terrorism, espionage, etc.). "should be reasonable" and not mere suspicions (REBECCA WALLACE, The principle of non-refoulement in international refugee law, in Research Handbook on International Law and Migration, Vincent Chetail and Céline Bauloz ed., Edward Elgar, 2014, p. 425).

It is also apparent from the art. 32 of the Convention on the Status of Refugees (the epigraph of which is "Expulsion") that:

"1. The Contracting States shall not expel a refugee lawfully in their territory save on grounds of national security or public order.

2. The expulsion of such a refugee shall be only in pursuance of a decision reached in accordance with due process of law. Except where compelling reasons of national security otherwise require, the refugee shall be allowed to submit evidence to clear himself, and to appeal to and be represented for the purpose before competent authority or a person or persons specially designated by the competent authority.

3. The Contracting States shall allow such a refugee a reasonable period within which to seek legal admission into another country. The Contracting States reserve the right to apply during that period such internal measures as they may deem necessary.”

It finally results from the art. $1 .^{\circ} \mathrm{F}(\mathrm{a})$ of the Convention on the Status of Refugees that certain categories of persons are excluded from the scope of their protection (those who have committed a crime against peace, a war crime or a crime against humanity, as defined in the international instruments drawn up to make provision in respect of such crimes).

The overwhelming majority of the doctrine favors the view that non-repulsion (non-refoulement) is a principle of customary international law, although there is still some debate on its nature (CATHRYN COSTELLO and MICHELLE FOSTER, Non-push back as Custom and Jus Cogens? Putting the Prohibition to the Test, in Netherlands Yearbook of International Law, Volume 46, 2015, p. 282), and there are even those who argue that it is ready to be recognized as jus cogens (Idem, p. 323). In Latin America, for example, Convention on the Status of Refugees is complemented by the so-called Cartagena Declaration on Refugees of 1984 and is the result of the Objectives of Section III:

"(5) To reiterate the importance and meaning of the principle of non-refoulement (including the prohibition of rejection at the frontier) as a corner-stone of the international protection of refugees. This principle is imperative in regard to refugees and in the present state of international law should be acknowledged and observed as a rule of jus cogens."

Although "the Cartagena Declaration is not legally binding", the countries of the region tend to mention it and some have even incorporated its provisions into national law (REBECCA WALLACE, The principle of non-refoulement in international refugee law, in Research Handbook on International Law and Migration, Vincent Chetail and Céline Bauloz ed., Edward Elgar, 2014, p. 421).

At the end of 2018, there were a total of 25.9 million refugees worldwide. INTERNATIONAL ORGANIZATION FOR MIGRATION, World Migration Report 2020, Geneva, 2019, p. 39. 
40. In view of the difficulties in obtaining an acceptable definition of services, the GATS merely defines "trade in services", described, according to the art. I (2), such as the supply of a service:

a) From the territory of one Member into the territory of any other Member (e.g. international telephone calls, information or advice transmitted by fax, telephone or mail electronic), i.e. only the service crosses borders and not the supplier or consumer thereof. This mode of service delivery is called cross-border supply or Mode 1;

b) In the territory of one Member to the service consumer of any other Member (e.g. tourism and repair of ships abroad), i.e. who moves is the consumer and hence this mode of service provision is known as consumption abroad (Mode 2);

c) By a service supplier of one Member, through commercial presence in the territory of any other Member (e.g. banks and hotel groups in country A are established in country B and supply services there). This mode of supply is called commercial presence (Mode 3 ) and covers any type of business or professional establishment through (i) the constitution, acquisition or maintenance of a juridical person, or (ii) the creation or maintenance of a branch or a representative office, within the territory of a Member for the purpose of supplying a service (art. XXVIII (d), of GATS);

d) By a service supplier of one Member, through presence of natural persons of a Member in the territory of any other Member (e.g. consultants from one country travel to another country and supply services there, the top-models). This mode of provision is called presence of natural persons or Mode 4.

It is apparent from the definition of the four modes of service provision that the GATS does not apply to purely internal situations. On the other hand, there is nothing to prevent commercial links between the various modes of service provision, for example, a foreign company established in country A having as national workers of country B and exporting services to countries C and D. Nothing prevents a particular type of service from being supplied through the different modes of supply (e.g. the services of a lawyer may be supplied through the four modes referred to). Nothing prevents, finally, that a service is supplied through the different technological means (telephone, Internet, fax, etc.), unless a WTO Member's list of appointments specifies otherwise.

41. A paternity of the art. V-A of the GATS should be credited to the so-called Nordic countries. JUAN MARCHETTI and PETROS MAVROIDIS, The Genesis of the CATS (General Agreement on Trade in Services), in European Journal of International Law, 2011, p. 714.

42. JÜRGEN BAST, Article Vbis GATS, in WTO - Trade in Services, Max Planck Commentaries on World Trade Law, Volume 6, Rüdiger Wolfrum, Peter-Tobias Stoll and Clemens Feinäugle ed., Martinus Nijhoff Publishers, 2008, p. 153. The current agreement replaced the previous Agreement Nordic of 22 May 1954. The Common Nordic Labor Market entered in vigor in 1 of July of 1954, abolishing the work permit requirement for citizens of other Nordic countries and the passport requirement. In 1955, an agreement was reached on social security, giving immigrants from Nordic countries more or less the same rights as national citizens. PEDER J. PEDERSEN, MARIANNE ROED and ESKIL WADENSJÖ, The extent of mobility, in The Common Nordic Labour Market at 50, Peder J. Pedersen, Marianne Røed and Eskil Wadensjö ed., TemaNord, Copenhagen, 2008, pp. 48-49.

43. WTO, Council for Trade in Services - Notification pursuant to Article Vbis of the General Agreement on Trade in Services (S/C/N/34), 2.12.1996, p. 2.

44. MARION PANIZZON, International Law of Economic Migration: A Household at Three? CATS Mode 4, EPAs, and Bilateral Migration Agreements, in Journal of World Trade, 2010, p. 1236.

45. WTO, A Handbook on Reading WTO Goods and Services Schedules, A WTO Secretariat Publication, Cambridge University Press, 2009, p. 38.

46. TIMOTHY HATTON, Should we have a WTO for international migration?, in Economic Policy, April 2007, p. 369. Other authors also note that GATS is about Mode 4 and not migration (ROMAN GRYNBERG and VENIANA QALO, Migration and the World Trade Organization, in Journal of World Trade, August 2007, p. 757). Despite the absence of a universally accepted definition of "migrant" (FRANCESCA CAPONE, The alleged tension between the Global Compact for Safe, Orderly and Regular Migration and state sovereignty: 'Much Ado about Nothing'?, in Leiden Journal of International Law, 2020, p. 713), the Recommendations on Statistics of International Migration of the United Nations define an "international migrant" as anyone who has changed their country of habitual residence, distinguishing between "short-term migrants" (those who have changed country of habitual residence for at least three months, but less than a year) and "longterm migrants" (those who have been doing so for at least a year). Not all countries use this definition in practice (INTERNATIONAL ORGANIZATION FOR MIGRATION, World Migration Report 2020, 
Geneva, 2019, p. 21). Another example: in the terms of paragraph 1 of the art. 11 Convention No 97 on Migrant Workers (revised 1949), the term 'migrant worker' means a person who migrates from one country to another with a view to being employed otherwise than on his own account; includes all persons regularly admitted as migrant workers. The history of the drafting of Convention No 97 and the subsequent interpretation of the supervisory body of the International Labour Organisation (Committee of Experts on the Application of Conventions and Recommendations) confirm that the definition of migrant workers includes refugees if they work outside their country of nationality. It follows that do not fall under the definition of undocumented migrant workers, self-employed migrant workers, frontier workers, persons who exercise a liberal profession and artists and sailors. The Convention No 143 on Immigration Made in Abusive Conditions and on the Promotion of Equal Opportunities and Treatment of Migrant Workers (1975) excludes two more categories of workers from the definition of migrant worker: individuals coming especially for training or education purposes; individuals employed by organisations or undertakings working in the territory of a country and who have been temporarily admitted to that country at the request of their employer in order to perform specific tasks or perform specific tasks for a limited and determined period and who must leave the country as soon as such functions or tasks are completed(art. 11, No 2). In accordance with the preparatory work of Convention No 143 and the interpretation of the Committee of Experts on the Application of Conventions and Recommendations, the last exception referred to is not all fixed-term workers, but mainly workers with special skills to perform specific and short-term technical tasks (VINCENT CHETAIL, International Migration Law, Oxford University Press, 2019, p. 202). There are also those who point out that International Labour Organisation Conventions 97 and 143 define the majority of GATS Mode 4 service suppliers as migrant workers, since the majority are nationals of one country and employed in another country (PHILIP MARTIN, Migrant Workers' vs. 'International Services Providers': Labour Markets and the Liberalization of Trade in Services', in The Internationalization of Labour Markets, Christiane Kuptsch ed., International Labour Organization / International Institute for Labour Studies, 2010, p. 218). Finally, for the International Organization for Migration, it does not matter to define a migrant whether the change is voluntary or not, what are its causes and whether the migrant's work is qualified or not. VINCENT CHETAIL, International Migration Law, Oxford University Press, 2019, p. 201.

47. JOEL TRACHTMAN, The International Law of Economic Migration: Toward the Fourth Freedom, W.E. Upjohn Institute for Employment Research, Michigan, 2009, p. 244.

48. "Trade in services is defined as the supply of a service: $d$ ) by a service supplier of one Member, through presence of natural persons of a Member in the territory of any other Member" (italics added).

49. JOHANNA JACOBSSON, GATS Mode 4 and Labour Mobility: The Significance of Employment Market Access, in The Palgrave Handbook of International Labour Migration: Law and Policy Perspectives, Marion Panizzon, Gottfried Zurcher and Elisa Fornale ed., Palgrave Macmillan, New York, 2015, p. 67. Legal entities of a WTO Member that supply services may employ citizens of any WTO Member, except the recipient country to carry out the transaction. (RUDOLF ADLUNG, The CATS - A Sleeping Beauty?, in Trade, Law and Development, 2020, p. 39). The Annex on the Movement of Natural Persons providing services under the GATS seems to welcome also the understanding that foreign individuals "employed by a service supplier of a Member" also include foreigners employed by companies in the recipient country. WTO, Presence of Natural Persons (Mode 4) - Background Note by the Secretariat (S/C/W/75), 8.12.1998, paragraph 56.

50. WTO, Presence of Natural Persons (Mode 4) - Background Note by the Secretariat (S/C/W/301), 15.9.2009, paragraph 13.

51. ANTONIA CARZANIGA, A warmer welcome? Access for natural persons under PTAs, in Opening Markets for Trade in Services: Countries and Sectors in Bilateral and WTO Negotiations, Juan Marchetti and Martin Roy ed., Cambridge University Press, 2008, p. 476.

52. TOMER BROUDE, The WTO/GATS Mode 4, international labor migration regimes and global justice, in Cosmopolitanism in Context: Perspectives from International and Political Theory, Roland Pierik and Wouter, Werner ed., Cambridge University Press, 2010, p. 77.

53. LAURA DAWSON, Labour Mobility and the WTO: The Limits of CATS Mode 4, in International Migration, vol. 51, n. ${ }^{\circ}$ 1, 2013, p. 8; WTO, Presence of Natural Persons (Mode 4) - Background Note by the Secretariat (S/C/W/301), 15.9.2009, p. 1.

54. However, the distinction between producing goods and services is not always easy, which may make the coverage of Mode 4 unclear. For example, foreign agricultural workers harvesting apples appear to be excluded from the GATS, but the WTO noted that temporary migrants working on a farm to harvest apples can be covered by Mode 4 because they provide "incidental services to agriculture". PHILIP MARTIN, Migrant Workers' vs. 'International Services Providers': Labour Markets and the Liberalization of Trade in 
Services', in The Internationalization of Labour Markets, Christiane Kuptsch ed., International Labour Organization / International Institute for Labour Studies, 2010, p. 202.

55. BERNARD HOEKMAN and ALAN WINTERS, Multilateralizing preferential trade agreements: a developing country perspective, in Multilateralizing Regionalism: Challenges for the Global Trading System, Richard Baldwin and Patrick Low ed., Cambridge University Press, 2009, p. 665.

56. JOY KATEGEKWA, Opening Markets for Foreign Skills: How Can the WTO Help? Lessons from the EU and Uganda's Regional Services Deals, Springer, 2014, p. 45.

57. MARION PANIZZON, Migration and Trade: Prospects for Bilateralism in the Face of Skill-Selective Mobility Laws, in Melbourne Journal of International Law, 2011, p. 110.

58. By early June 2020, Convention No 97 had been ratified by 50 countries and Convention No 143 by only 25 countries Parties. https://www.ilo.org/dyn/normlex/en/f?p=1000:12001::NON::.: The non-ratification of a Convention of the International Labour Organization does not imply, however, that it does not have to be observed on the territory of a particular country. For instance, the United States-Mexico-Canada Agreement (USMCA) establishes in the art. 23.3 that:

1. Each Party shall adopt and maintain in its statutes and regulations, and practices thereunder, the following rights, as stated in the ILO Declaration on Rights at Work:3, 4, 5

(a) freedom of association6 and the effective recognition of the right to collective bargaining;7

(b) the elimination of all forms of forced or compulsory labor;

(c) the effective abolition of child labor and, for the purposes of this Agreement, a prohibition on the worst forms of child labor; and

(d) the elimination of discrimination in respect of employment and occupation.

3. The obligations set out in this Article, as they relate to the ILO, refer only to the ILO Declaration on Rights at Work.

4. A failure to comply with an obligation under paragraphs 1 or 2 must be in a manner affecting trade or investment between the Parties. For greater certainty, a failure is "in a manner affecting trade or investment between the Parties" if it involves: (i) a person or industry that produces a good or supplies a service traded between the Parties or has an investment in the territory of the Party that has failed to comply with this obligation; or (ii) a person or industry that produces a good or supplies a service that competes in the territory of a Party with a good or a service of another Party.

5. For purposes of dispute settlement, a panel shall presume that a failure is in a manner affecting trade or investment between the Parties, unless the responding Party demonstrates otherwise.

6. For greater certainty, the right to strike is linked to the right to freedom of association, which cannot be realized without protecting the right to strike.

7. Annex 23-A (Worker Representation in Collective Bargaining in Mexico) sets out obligations with regard to worker representation in collective bargaining."

59. PHILIP MARTIN, Migrant Workers' vs. 'International Services Providers': Labour Markets and the Liberalization of Trade in Services', in The Internationalization of Labour Markets, Christiane Kuptsch ed., International Labour Organization / International Institute for Labour Studies, 2010, p. 205. 50 WTO members had then qualified their national treatment obligations by introducing wage parity requirements. MARION PANIZZON, International Law of Economic Migration: A Household at Three? CATS Mode 4, EPAs, and Bilateral Migration Agreements, in Journal of World Trade, 2010, p. 1223.

60. The legal value of the Annex on the Movement of Natural Persons Supplying Services under the GATS is not less than that of the GATS text itself. JAN SCHMITZ, The Temporary Movement of Natural Persons in the Context of Trade in Services: EU Trade Policy under Mode 4 (WTO/GATS), in The Palgrave Handbook of International Labour Migration: Law and Policy Perspectives, Marion Panizzon, Gottfried Zurcher and Elisa Fornale ed., Palgrave Macmillan, New York, 2015, p. 388.

61. WTO, World Trade Report 2004: Exploring the linkage between the domestic policy environment and international trade, WTO Publications, Geneva, 2004, p. 46.

62. The standard model of a list of specific appointments has three columns: Column 1 concerns market access, Column 2 to National Treatment, and Column 3 to additional commitments. In the first column, a WTO Member, when it makes a commitment in a sector or subsector, shall indicate in relation to each mode of supply what possible limitations it maintains in relation to market access. Unless otherwise indicated, you may only decide to adopt or maintain six categories of restrictions (those indicated in paragraph 2 of Article XVI do GATS). In the second column, a Member shall indicate the limitations on national treatment which he wishes to maintain. In the case of the third column, entries are not mandatory, i.e. a Member may decide at any given time to make additional commitments for measures other than those to be included in the 
columns relating to market access and national treatment. These additional commitments may concern, for example, qualifications, technical standards, processes or licensing requirements, as well as other internal regulations. On the other hand, to designate commitments, the following expressions are used: "None" describes a total commitment, i.e. there is no limitation or legislation incompatible with the rules on market access and national treatment for services and service suppliers of other members; "Unbound" or "Unconsolidated" refers to the fact that a WTO Member may adopt or maintain measures incompatible with the rules on market access or national treatment. The use of this expression is relevant only when a commitment has been made in a sector for at least one mode of supply. Where all modes of supply are unconsolidated and no additional commitments have been made in the sector concerned, that sector will not be on the list. In a way, a commitment can be between $0 \%$ (unbound) and $100 \%$ (none). In certain situations, a certain mode of delivery may not be technically possible. This is the case, for example, with the crossborder provision of a haircut. In these cases, the term "Unconsolidated*" should be used [Unbound*]. Furthermore, where a supply of services requires in practice the use of more than one form of supply, the coverage of the transaction is only ensured when commitments are made in each relevant form of supply. For example, if a member is committed to the cross-border provision of architectural services (by mail), this commitment alone does not cover the presence of natural persons (the visit of architects). Finally, in order to avoid repetitions, almost all countries have reserved a section at the beginning of their lists for so-called "horizontal commitments" on measures applicable to all sectors listed. This may result in limitations applicable to all sectors in relation to any mode of supply. It is appropriate to check the existence and nature of the horizontal section of a list before reading the line corresponding to a specific sector in the second part of the list. Most members include horizontal commitments as a way to limit the movement of individuals in all registered service sectors, making it difficult for unemployed visitors to enter.

63. WTO, World Trade Report 2004: Exploring the linkage between the domestic policy environment and international trade, WTO Publications, Geneva, 2004, p. 55.

64. LAURA DAWSON, Labour Mobility and the WTO: The Limits of CATS Mode 4, in International Migration, vol. 51, no. 1, 2013, p. 10.

65. JOEL TRACHTMAN, The International Law of Economic Migration: Toward the Fourth Freedom, W.E. Upjohn Institute for Employment Research, Michigan, 2009, p. 246.

66. The term "brain drain" was coined by the British Royal Society to refer to the exodus of scientists and technologists from the United Kingdom to the United States and Canada in the 1950s and 1960s. JOHN GIBSON and DAVID MCKENZIE, Eight Questions about Brain Drain, in Journal of Economic Perspectives, Volume 25, Number 3, Summer 2011, p. 108.

67. In contrast, the "brain waste" concerns a disuse of skills, ending migrants working in occupations that require qualifications lower than those acquired in their countries of origin. INTERNATIONAL ORGANIZATION FOR MIGRATION, World Migration Report 2020, Geneva, 2019, p. 176.

68. FRÉDÉRIC DOCQUIER and HILLEL APOPORT, Brain Drain, in The New Palgrave Dictionary of

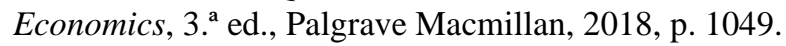

69. WTO, Presence of Natural Persons (Mode 4) - Background Note by the Secretariat (S/C/W/301), 15.9.2009, paragraph 52.

70. WITADA ANUKOONWATTAKA and ADAM HEAL, Regional Integration and Labour Mobility: Linking Trade, Migration and Development, United Nations Publication, 2014, p. 36.

71. JAGDISH BHAGWATI, The brain drain, in International Social Science Journal, Vol. XXVIII, N. ${ }^{\circ} 4,1976$, pp. $722-724$.

72. CARLOS VARGAS-SILVA, The Fiscal Impact of Immigrants: Taxes and Benefits (Chapter 16), in Handbook of the Economics of International Migration, Elsevier 2015, p. 869.

73. JÓZSEF GOLOVICS, Addressing the EU's East-West Brain Drain: Why a Tax Solution Would Be in Vain, in New Perspectives Vol. 27, N. ${ }^{\circ}$ 2/2019, pp. 67-68.

74. JOEL TRACHTMAN, The International Law of Economic Migration: Toward the Fourth Freedom, W.E. Upjohn Institute for Employment Research, Michigan, 2009, pp. 80-81.

75. By 2050, OECD countries will see more people retire than entering the labour market. REBEKAH SMITH and FARAH HANI, Labor Mobility Partnerships: Expanding Opportunity with a Globally Mobile Workforce, Final Report of the Connecting International Labor Markets Working Group, Center for Global Development, Washington, DC, 2020, p. 2.

76. OECD, International Migration Outlook 2019, OECD Publishing, Paris, 2019, p. 40. In 1960, about 85\% of foreign-born people living in the United States were originally from Europe and Canada, but this percentage 
shrank to 13\% in 2016. HEIN DE HAAS ET AL., International Migration: Trends, Determinants, and Policy Effects, Population and Development Review, December 2019, p. 889.

77. INTERNATIONAL ORGANIZATION FOR MIGRATION, World Migration Report 2020, Geneva, 2019, p. 176.

78. THE ECONOMIST, Global Migration - Locked out, 1.8.2020, p. 11.

79. KIMBERLY CLAUSING, Open: The Progressive Case for Free Trade, Immigration, and Global Capital, Harvard University Press, 2019, pp. 182-183.

80. SARI PEKKALA KERR, WILLIAM KERR, ÇAGLAR ÖZDEN and CHRISTOPHER PARSONS, Global Talent Flows, in Journal of Economic Perspectives, Volume 30, Number 4, Fall 2016, p. 86.

81. KIMBERLY CLAUSING, Open: The Progressive Case for Free Trade, Immigration, and Global Capital, Harvard University Press, 2019, p. 181.

82. JASON FURMAN, Nationalism, Immigration, and Economic Success, OP-EDS, Peterson Institute for International Economics, 18.7.2018; THE ECONOMIST, Special report Migration, 16.11.2019, p. 5.

83. THOMAS COTTIER and CHARLOTTE SIEBER-GASSER, Labour Migration, Trade and Investment: From Fragmentation to Coherence, in The Palgrave Handbook of International Labour Migration: Law and Policy Perspectives, Marion Panizzon, Gottfried Zurcher and Elisa Fornale ed., Palgrave Macmillan, New York, 2015, p. 55.

84. ANTONIA CARZANIGA, The GATS, Mode 4, and Pattern of Commitments, in Moving People to Deliver Services, Aaditya Mattoo and Antonia Carzaniga ed., World Bank/Oxford University Press, 2003, p. 24.

85. THOMAS COTTIER and CHARLOTTE SIEBER-GASSER, Labour Migration, Trade and Investment: From Fragmentation to Coherence, in The Palgrave Handbook of International Labour Migration: Law and Policy Perspectives, Marion Panizzon, Gottfried Zurcher and Elisa Fornale ed., Palgrave Macmillan, New York, 2015, pp. 49-50.

86. In 2017, the commercial presence (Mode 3) was the dominant way of supplying services globally (58.9\%), representing financial services and distribution services about half of this value; cross-border services (Mode 1), including those supplied by electronic means, had a share of $27.7 \%$, consumption abroad (Mode 2) a weight of $10.4 \%$ and the presence of natural persons (Mode 4) a share of 2.9\%. WTO, World Trade Report 2019: The future of services trade, WTO Publications, Geneva, 2019, pp. 22 and 24.

87. With regard to commitments connected to Mode 4, the H-1B programme allows Employers in the United States to easily obtain visas of up to six years for foreigners with a university degree or more (PAOLO E. GIORDANI and MICHELE RUTA, Coordination Failures in Immigration Policy, Staff Working Paper ERSD 2011-02 World Trade Organization - Economic Research and Statistics Division, 26.1.2011, p. 21; PHILIP MARTIN, Migrant Workers' vs. 'International Services Providers': Labour Markets and the Liberalization of Trade in Services', in The Internationalization of Labour Markets, Christiane Kuptsch ed., International Labour Organization / International Institute for Labour Studies, 2010, p. 201). The estimated total number of H-1B visa holders in the United States in fiscal 2017 reached nearly one million and the weight of Indian citizens in this category reached an astounding $74 \%$, or about 727,000 highly skilled workers. JACOB FUNK KIRKEGAARD, The US H-1B Visa: A Boon for High-Skilled Immigrants from India, Realtime Economic Issues Watch, Peterson Institute for International Economics, 19.11.2019.

88. WTO, World Trade Report 2019: The future of services trade, WTO Publications, Geneva, 2019, p. 28.

89. REGIS SIMO, Trade in Services in the African Continental Free Trade Area: Prospects, Challenges and WTO Compatibility, in Journal of International Economic Law, 2020, p. 86.

90. ROMAN GRYNBERG and VENIANA QALO, Migration and the World Trade Organization, in Journal of World Trade, August 2007, p. 755.

91. BERNARD HOEKMAN and AADITYA MATTOO, International trade: trade in services, in Research Handbook in International Economic Law, Andrew Guzman and Alan O. Sykes ed., Edward Elgar, Cheltenham, United Kingdom-Northampton, United States of America, 2007, p. 141.

92. BERNARD HOEKMAN and MICHEL KOSTECKI, The Political Economy of the World Trading System: The WTO and Beyond, 3. ${ }^{a}$ ed., Oxford University Press, 2009, p. 355.

93. It is difficult to apply in the context of the services safeguard measures of the kind provided for in art. XIX of the General Agreement on Tariffs and Trade (GATT), since services, not subject to storage, are less subject to such high increases that cause or threaten to cause serious injury to national suppliers of similar services or directly competitors, in addition to that "the intangible nature of the provision of the service creates difficulties when trying to compare a foreign service with a national service" (GILLES GAUTHIER, ERIN O'BRIEN and SUSAN SPENCER, Déjà Vu, or New Beginning for Safeguards and Subsidies Rules in Services Trade?, in GATS 2000: New Directions in Services Trade Liberalization, Pierre Sauvé and Robert 
Stern ed., Brookings Institution Press, Washington, D.C., 2000, p. 171). The well-known shortcomings of statistical data on trade in services also make it difficult to prove in a timely manner, in particular for developing countries, that serious injury has occurred, as well as to establish the causal link.

94.

. 11-12. disconnected from commercial presence, contain more provisions that facilitate mobility and even include social and economic rights for spouses and dependent on "Mode 4" workers. SANDRA LAVENEX, The trade-migration nexus: Multilateral stalemate versus regional and bilateral dynamics, International Centre for Trade and Sustainable Development (ICTSD), Geneva, 19.11.2018.

99. JOOST PAUWELYN, TRUNG NGUYEN and KHALID KAMAL, Visa and Asylum, in Handbook of Deep Trade Agreements, Aaditya Mattoo, Nadia Rocha and Michele Route ed., Washington, DC, 2020, pp. 240 and 245.

100. JACQUES PELKMANS, Business dimensions of EU's new FTAs, in Journal of European Integration, 2017, p. 787.

101. VINCENT CHETAIL, International Migration Law, Oxford University Press, 2019, p. 97.

102. JOOST PAUWELYN, TRUNG NGUYEN and KHALID KAMAL, Visa and Asylum, in Handbook of Deep Trade Agreements, Aaditya Mattoo, Nadia Rocha and Michele Route ed., Washington, DC, 2020, pp. 245246.

103. GIANLUCA OREFICE, Managing global value chains and migration through deep preferential trade agreements, International Centre for Trade and Sustainable Development (ICTSD), Geneva, 19.11.2018.

104. THOMAS COTTIER and CHARLOTTE SIEBER-GASSER, Labour Migration, Trade and Investment: From Fragmentation to Coherence, in The Palgrave Handbook of International Labour Migration: Law and Policy Perspectives, Marion Panizzon, Gottfried Zurcher and Elisa Fornale ed., Palgrave Macmillan, New York, 2015, p. 52.

105. SHERRY STEPHENSON and GARY HUFBAUER, Labor Mobility, in Preferential Trade Agreement Policies for Development: A Handbook, Jean-Pierre Chauffour and Jean-Christophe Maur ed., The World Bank, Washington, D.C., 2011, p. 290. If all visa and work permit requirements between two countries are eliminated, the deviation from Most Favored Nation treatment inherent in a bilateral migration agreement is justified under the exception of GATS art V-A, i.e. we will be in the face of an agreement on labour market integration. MARION PANIZZZON, Standing together apart: Bilateral migration agreements and the temporary movement of persons under "mode 4" of GATS, Centre on Migration, Policy and Society Working Paper No. 77, University of Oxford, 2010, p. 17.

106. OECD, International Migration Outlook 2019, OECD Publishing, Paris, 2019, p. 25.

107. ROMAN GRYNBERG and VENIANA QALO, Migration and the World Trade Organization, in Journal of World Trade, August 2007, p. 761.

108. SHERRY STEPHENSON and GARY HUFBAUER, Labor Mobility, in Preferential Trade Agreement Policies for Development: A Handbook, Jean-Pierre Chauffour and Jean-Christophe Maur ed., The World Bank, Washington, D.C., 2011, p. 287.

109. MICHAEL A. CLEMENS, ETHAN G. LEWIS and HANNAH M. POSTEL, Immigration Restrictions as Active Labor Market Policy: Evidence from the Mexican Bracero Exclusion, in American Economic Review, 2018, p. 1649.

110. OECD, International Migration Outlook 2019, OECD Publishing, Paris, 2019, p. 157.

111. T. ALEXANDER ALEINIKOFF, Toward a Global System of Human Mobility: Three Thoughts, in American Journal of International Law Unbound, Vol. 111, 2017, p. 24.

112. JOHN GIBSON and DAVID MCKENZIE, Eight Questions about Brain Drain, in Journal of Economic Perspectives, Volume 25, Number 3, Summer 2011, p. 111.

113. ALAN WINTERS, The Temporary Movement of Workers to Provide Services (GATS Mode 4), in $A$ Handbook of International Trade in Services, Aaditya Mattoo, Robert Stern and Gianni Zanini ed., Oxford University Press, 2008, p. 480. 
114. GEORGE J. BORJAS, International Migration, in The New Palgrave Dictionary of Economics, 3. ${ }^{a}$ ed., Palgrave Macmillan, 2018, p. 6765.

115. Ironically, during the colonial era, Britain transported real criminals to the territory that now corresponds to the United States (MARGARET PETERS, Trading barriers: immigration and the remaking of globalization, Princeton University Press, 2017, p. 222). It should be noted that immigrants in the United States are generally far less likely than natives to commit crimes or to be arrested. RYAN NUNN, JIMMY O'DONNELL and JAY SHAMBAUGH, A Dozen Facts about Immigration, The Hamilton Project, Washington, DC, 2018, p. 14.

116. THE NEW YORK TIMES, Trump Says U.S. Will Hit Mexico With 5\% Tariffs on All Goods, 30.5.2019.

117. Perhaps because, as Mexico in 2018 exported to the United States products worth $\$ 346.5$ billion worth of goods, a 5\% customs duty on these goods would amount to a tax increase of more than $\$ 17$ billion. Of course, most of the costs would be passed on to US companies and consumers (THE NEW YORK TIMES, Trump Says U.S. Will Hit Mexico With 5\% Tariffs on All Goods, 30.5.2019). It is also estimated that the contribution of illegal immigrants themselves in the case of the United States is approximately $2.6 \%$ of GDP. RYAN NUNN, JIMMY O'DONNELL and JAY SHAMBAUGH, A Dozen Facts about Immigration, The Hamilton Project, Washington, DC, 2018, p. 10.

118. OECD, International Migration Outlook 2019, OECD Publishing, Paris, 2019, p. 100.

119. JAMES C. HATHAWAY and THOMAS GAMMELTOFT-HANSEN, Non-Refoulement in a World of Cooperative Deterrence, in Columbia Journal of Transnational Law, 2015, p. 236.

120. THE WASHINGTON POST, Long-term maintenance for Trump's border wall could cost billions, but government isn't saying, 5.2.2020.

121. OECD/ILO, How Immigrants Contribute to Developing Countries' Economies, OECD Publishing, Paris, 2018, p. 18.

122. FLORENCE JAUMOTTE, KSENIA KOLOSKOVA and SWETA CHAMAN SAXENA, Impact of Migration on Income Levels on Advanced Economies (Spillover Task Force), International Monetary Fund, October 2016, p. 2.

123. OECD, International Migration Outlook 2019, OECD Publishing, Paris, 2019, p. 154.

124. VINCENT CHETAIL, International Migration Law, Oxford University Press, 2019, pp. 4-5.

125. REBEKAH SMITH and FARAH HANI, Labor Mobility Partnerships: Expanding Opportunity with a Globally Mobile Workforce, Final Report of the Connecting International Labor Markets Working Group, Center for Global Development, Washington, DC, 2020, p. 2.

126. KIMBERLY CLAUSING, Open: The Progressive Case for Free Trade, Immigration, and Global Capital, Harvard University Press, 2019, p. 189.

127. So-called remittances are financial or in-kind transfers made by migrants directly to families or communities in their countries of origin. Remittances to low- and middle-income countries reached a record \$529 billion in 2018, nearly $10 \%$ more than the previous year, and are the largest source of external funding for those countries (three times larger than foreign aid). In the case of the least developed countries, remittances of migrant workers accounted for 7\% of GDP in 2019 (WTO, The COVID-19 Pandemic and Trade-Related Developments in LDCs - Information Note, 8.6.2020, p. 4). In 2018, India, China, Mexico, the Philippines and Egypt were (in descending order) the top five recipient countries of remittances, although India and China were well above the rest, with shipments in excess of $\$ 67$ billion for each country. In terms of percentage of GDP, the top five remittance receiving countries in 2018 were: Tonga (35.2\%), Kyrgyzstan $(33.6 \%)$, Tajikistan (31\%), Haiti (30.7\%) and Nepal (28\%). As regards the origin of remittances (2017), US $\$ 68$ billion originated in the United States, followed by the United Arab Emirates (44 billion), Saudi Arabia (US $\$ 36$ billion), Switzerland (US $\$ 26$ billion) and Germany (US $\$ 22$ billion) (INTERNATIONAL ORGANIZATION FOR MIGRATION, World Migration Report 2020, Geneva, 2019, p. 36). It should also be noted that the actual magnitude of global shipments is likely to be greater than the available estimates, since advanced data does not capture, for example, flows through informal channels. Finally, note that global remittances in 1970 were estimated at just over \$3 billion. FIONA ADAMSON, Crossing Borders: International Migration and National Security, in International Security, Vol. 31, N. ${ }^{\circ}$ 1, Summer 2006, p. 187.

128. AJAY BAILEY, Global Migration: Current Trends and Issues, in Issues in International Migration Law, Richard Plender ed., Brill, Leiden, 2015, p. 13.

129. ANDRÉS SOLIMANO, International Migration in the Age of Crisis and Globalization: Historical and Recent Experiences, Cambridge University Press, 2010, p. 66.

130. THE ECONOMIST, Special report Migration, 16.11.2019, p. 7. 
131. WTO, World Trade Report 2004: Exploring the linkage between the domestic policy environment and international trade, WTO Publications, Geneva, 2004, pp. 47-48.

132. JOEL TRACHTMAN, The International Law of Economic Migration: Toward the Fourth Freedom, W.E. Upjohn Institute for Employment Research, Michigan, 2009, p. 60.

133. WTO, World Trade Report 2004: Exploring the linkage between the domestic policy environment and international trade, WTO Publications, Geneva, 2004, p. 53.

134. FRÉDÉRIC DOCQUIER and HILLEL APOPORT, Brain Drain, in The New Palgrave Dictionary of Economics, 3. ${ }^{\text {a }}$ ed., Palgrave Macmillan, 2018, p. 1051.

135. Between 1990 and 2010, the number of migrants with a higher education degree increased by almost $130 \%$, but the number of primary school migrants increased by only $40 \%$ (SARI PEKKALA KERR, WILLIAM KERR, ÇAGLAR ÖZDEN and CHRISTOPHER PARSONS, Global Talent Flows, in Journal of Economic Perspectives, Volume 30, Number 4, Fall 2016, p. 83). Even if they represent less of one-fifth of the world's population, OECD countries host two-thirds of highly skilled migrants. Idem, p. 85.

136. JOHN GIBSON and DAVID MCKENZIE, Eight Questions about Brain Drain, in Journal of Economic Perspectives, Volume 25, Number 3, Summer 2011, p. 116.

137. Idem, p. 109.

138. Idem, p. 117.

139. TOMAN BARSBAI, HILLEL RAPOPORT, ANDREAS STEINMAYR and CHRISTOPH TREBESCH, The Effect of Labor Migration on the Diffusion of Democracy: Evidence from a Former Soviet Republic, in American Economic Journal: Applied Economics 2017, pp. 36-69.

140. However, some recent cases show that emigration to Western democracies has not brought a democratic dividend to the countries of origin, at least for now. For instance:

"Decades of Cuban immigration to the United States or of Iranian immigration to the West arguably did little to promote democracy in Cuba or Iran. The factors that explain the democratic effects of emigration may have to do with the extent to which migrants can retain close ties and freely communicate with their home communities, as suggested in this paper, but also, possibly, with the cultural distance between home and host countries, the degree of social integration of immigrants in the host societies, or with the circumstances that led to emigration in the first place." Idem, p. 66.

141. The United Nations General Assembly adopted the 2030 Agenda for Sustainable Development (Agenda 2030) in September 2015. The Agenda consists of 17 Sustainable Development Goals and 169 associated goals. The objectives and goals were formulated by through a participatory process that involved states, global civil society and many others actors and aim to combat poverty, inequality, hunger, climate change, etc. For larger developments, INTERNATIONAL ORGANIZATION FOR MIGRATION, Migration and the 2030 Agenda: A Guide for Practitioners, Geneva, 2018.

142. THOMAS COTTIER and CHARLOTTE SIEBER-GASSER, Labour Migration, Trade and Investment: From Fragmentation to Coherence, in The Palgrave Handbook of International Labour Migration: Law and Policy Perspectives, Marion Panizzon, Gottfried Zurcher and Elisa Fornale ed., Palgrave Macmillan, New York, 2015, pp. 41-42.

143. RICHARD BALDWIN, The Globotics Upheaval: Globalization, Robotics, and the Future of Work, Oxford University Press, 2019, p. 15. In 2017, French presidential candidate Jean-Luc Mélenchon, campaigned in Lyon and Marseille at the same time, using a holographic projection. Idem, p. 134.

144. Idem, p. 7.

145. Idem, p. 228.

146. RICHARD BALDWIN and RIKARD FORSLID, Globotics and Development: When Manufacturing is Jobless and Services are Tradable, NBER Working Paper No. 26731, February 2020, p. 24.

147. ANU BRADFORD, Sharing the Risks and Rewards of Economic Migration, in University of Chicago Law Review, 2013, p. 31.

148. INTERNATIONAL ORGANIZATION FOR MIGRATION, Migration and the 2030 Agenda: A Guide for Practitioners, Geneva, 2018, p. 11. 